\title{
EFFECT OF SEWAGE-CONTAMINATED WATER ON SEED PRODUCTION, HEAVY METALS ACCUMULATION AND SEEDLING EMERGENCE IN OAT
}

\section{MORADIS. \\ HEIDARI H. \\ SAEIDI M. \\ NOSRATTI I.}

Received: 19/11/2016

Accepted: 04/05/2016

Available online: $10 / 05 / 2016$

\author{
Department of Agronomy and Plant Breeding \\ Faculty of Agricultural Science and Engineering
}

Razi University, Kermanshah, Iran

\section{ABSTRACT}

Two pot experiments were carried out to investigate effect of deficit irrigation with wastewater on seed yield, heavy metals and seedling emergence in oat (Avena sativa). The research at seedling stage included different ratios of sewage-contaminated water ( $100 \%$ well water, $75 \%$ well water $+25 \%$ wastewater, $50 \%$ well water $+50 \%$ wastewater, $25 \%$ well water $+75 \%$ wastewater and $100 \%$ wastewater) and three irrigation intervals (1,2 and 3 days). The research at complete plant stage included different ratios of sewage-contaminated water used at seedling stage and irrigation intervals of 2, 3 and 4 days. Results showed that at oat seedling stage, irrigation interval of 1 days and $100 \%$ wastewater produced the highest seedling weight. Irrigation interval of 3 days with $100 \%$ wastewater had the lowest seedling emergence. At complete plant stage, by increasing wastewater concentration, leaf chlorophyll content was increased, but relative water content was decreased. 100\% wastewater produced the highest seed yield, 1000-seed weight, concentrations of zinc, copper and potassium. According to references, the concentration of studied heavy metals was lower than dangerous threshold.

Keywords: Chlorophyll, drought, heavy metals, oat, seed yield, sewage

\section{Introduction}

Fresh water sources restriction is a serious problem in many countries. Agriculture uses 91 percentages of annual fresh water sources in Iran (Babran and Honarbakhsh, 2008). Using wastewater is a common way for drought management in agriculture and industry. Some uses of wastewater in the world are irrigation of forest, rangelands and forage crops (Moosavi et al., 2013). Nowadays, $80 \%$ of wastewater is used to irrigate farms contributing in 70-80 \% of food safety (Mara and Cairncross, 1989). In 1980, about $60 \%$ of America wastewater has been used in agriculture. In recent years, 7 million cubic meters of wastewater enter into arable lands, daily (Brady, 1990). Many researchers have studied wastewater reuse effects on plants and soil. Malabar spinach plant irrigated by treated wastewater with gamma radiation showed better growth than plants irrigated by underground fresh water (Bhuiyan et al., 2016). Reuse of cheese whey wastewater for tomato production had no significant effect on marketable yield and production losses. Treated wastewater reduced fruit epidermis deformations due to solar exposition (Prazeres et al., 2016). Heavy metals are metals that their densities are more than $5 \mathrm{~g} \mathrm{~cm}^{-3}$ (Pais and Benton, 1997). Some heavy metals such as $\mathrm{Cu}$ and $\mathrm{Mn}$ are essential for plant growth, but their high concentration in soil can poison and inhibit plant growth (Marschner, 1995). Soil copper toxicity can be both natural (such as mines) and artificial due to man activities (such as fertilizers) (Kopittke, 2006). High concentration of copper reduces plant biomass and destroys chloroplast (Schaller, 2003). Heavy metals 
$(\mathrm{Pb}, \mathrm{Cd}$ and $\mathrm{As})$ inhibited growth and elevated enzymatic response in yellow lupine roots (Jomova and Morovi, 2009). Chojnacka et al. (2005) found that the correlation between total contents of heavy metals in soil and plants was low. Correlation between citrate-soluble fractions (not between total soil concentration) and the plant for metals was linear. This suggests that plant absorption is controlled by the composition of the soil solution. Potassium activates many enzymes because of its high concentration in cell and soil. The nutrient involves in carbon exchange rate and water use efficiency (Salardiny, 2005). Salinity caused by $\mathrm{NaCl}$ decreased potassium concentration, but increased sodium concentration in canola (Brassica napus L.) tissues (Bahrani, 2013). Seed germination traits as indexes of tolerance to contamination were studied in many researches (Jadia and Fulekar, 2008; Barua et al., 2011). For example Li et al. (2005) reported that Arabidopsis thaliana seedling growth was more sensitive to heavy metals (such as $\mathrm{Cu}$ and $\mathrm{Zn}$ ) than that of seed germination. Oat (Avena sativa) is a tolerant plant to unfavorable soil and it is newly introduced to farmers for cultivation in Iran. There is no reliable statistic for oat production in Iran. The annual global production and cultivated areas of oat are 22.5 million tons and 9.7 million hectares, respectively (Yara, 2015). Regarding water shortage and wastewater entering into rivers daily, it is essential to find a safe way to use the wastewater with at least risk for human and environment health. So the purposes of the study were: 1 ) to find the optimum deficit irrigation with wastewater to achieve the highest seed yield quality and quantity. 2) to determine the tolerance of oat seed to wastewater and deficit irrigation at seedling emergence stage.

\section{Materials and methods}

\subsection{Experiment at Seedling Stage}

A pot experiment was carried out at The Research Greenhouse, Campus of Agriculture and Natural Resources, Razi University, Kermanshah in 2012-2013. Oat seed (Avena sativa cv. 'Tarahumara') was prepared from seed bank in Razi University. 10 oat seeds were sown per pot $(7 \mathrm{~cm}$ in diameter, $12 \mathrm{~cm}$ in depth) filled by farm soil. The study was a factorial experiment based on a completely randomized design with four replications. The first factor was different ratios of sewage-contaminated water $(100 \%$ well water, $75 \%$ well water $+25 \%$ wastewater, $50 \%$ well water $+50 \%$ wastewater, $25 \%$ well water + $75 \%$ wastewater and $100 \%$ wastewater). The second factor included three irrigation intervals of 1, 2 and 3 days. The optimum irrigation interval ( 1 day) was determined by a pre-experiment according to plant and soil symptoms. Irrigation interval of 2 and 3 days were moderate and severe drought. Wastewater samples were collected from Gharasoo River in Kermanshah city gradually during plant growth. Nearly all wastewater produced in Kermanshah city discharges into the river. The treatments were applied at the beginning of the experiment and continued for 15 days. At the end of the experiment, emergence percentage, seedling height and seedling dry weight were measured. Seedling was oven-dried at $70^{\circ} \mathrm{C}$ for $48 \mathrm{~h}$.

\subsection{Experiment at Complete Plant Stage}

A pot experiment was carried out at the Research Greenhouse, Campus of Agriculture and Natural Resources, Razi University, Kermanshah in 2012-2013. The pots ( $23 \mathrm{~cm}$ in diameter, $25 \mathrm{~cm}$ in depth) were filled by farm soil (60\%), sand (20\%) and animal dung (20\%) then 12 oat seeds were sown within each pot. After emergence, oat (cv. 'Tarahumara') seedlings were thinned and four seedlings were remained per pot. The study was conducted as a factorial experiment based on a randomized complete block design with three replications. The first factor was different ratios of sewage-contaminated water $100 \%$ well water, $75 \%$ well water $+25 \%$ wastewater, $50 \%$ well water $+50 \%$ wastewater, $25 \%$ well water $+75 \%$ wastewater and $100 \%$ wastewater). The second factor included three irrigation intervals of 2, 3 and 4 days. The optimum irrigation interval ( 2 days) was determined by a pre-experiment according to plant and soil symptoms. Irrigation interval of 3 and 4 days were moderate and severe drought. The treatments were applied at heading stage and continued to a week before harvesting. Studied traits were leaf relative water content (RWC), chlorophyll content, leaf area, stem dry weight, leaf dry weight, number of seed per panicle, seed yield, thousand seed weight, biological yield and concentrations of zinc, copper, sodium 
and potassium in the seed. Flag leaf was used to calculate relative water content by Eq. 1. (Gunes et al., 2008).

$$
\text { RWC }=[(F W-D W) /(T W-D W)] \times 100 \%
$$

Where FW, DW and TW are fresh weight, dry weight and turgid weight, respectively. Leaf elative water content was measured at three times (14, 17 and 20 days after treatment imposing). Average values of three times were used for calculating relative water content. Flag leaf chlorophyll content was measured using SAPD device 14 days after treatment imposing at three times (weekly). Leaf area (LA) was measured by calculating leaf width (W) and leaf length (L) using Eq. 2. (Chaab et al., 2009).

$$
L A=W * L * 0.75
$$

Three plans were cut 115 days after sowing and 1000-seed weight and seed number per panicle were measured. Aboveground biomass was oven-dried at $70^{\circ} \mathrm{C}$ for $48 \mathrm{~h}$. To determine elements concentration, $2 \mathrm{~g}$ of powdered plant samples were ashed using electric oven then the ash samples were dissolved into hydrogen chloride. Finally the samples were filtered using filter paper. Copper and zinc concentrations were determined using atomic absorption device (Spectra AA 220 model) at 324.2 and $213.9 \mathrm{~nm}$ wavelengths, respectively. Sodium and potassium concentrations were determined using flame photometer device (JENWAY PEP7) at 598 and $766.5 \mathrm{~nm}$ wavelengths, respectively (Meftahi, 2011).

\subsection{Statistical Analyses}

Data were analyzed using MSTATC and SAS softwares. Means were compared by Duncan test at $P<0.05$. Only significant data were shown.

\section{Results and discussion}

\subsection{Experiment at Seedling Stage}

Seeding Emergence Percentage: Under drought (irrigation interval of 3 days), by increasing wastewater concentration, seedling emergence reduced. Irrigation interval of 3 days with $100 \%$ wastewater had the lowest seedling emergence (Fig. 1). It was probably due to accumulation of heavy metals and salts around seed that reduced water suction by the seed (Rahimi et al., 2006).

Seedling Height and Weight: By increasing wastewater concentration, seedling height and weight were increased, but drought reduced seedling height and weight (Fig. 1). Increasing plant height by wastewater was reported by Yoon and Kwun, (2001) in rice. Kaya et al. (2006) reported that salinity and drought reduced sunflower (Helianthus annus L.) seedling weight that is in agreement with our result. Wastewater contains essential nutrients for plant growth, so it can promote plant growth. Seedling height reduction by drought is due to reduction in cell division and enlargement.

S1, S2, S3, S4 and S5 are different ratios of sewage-contaminated water ( $100 \%$ well water, $75 \%$ well water $+25 \%$ wastewater, $50 \%$ well water $+50 \%$ wastewater, $25 \%$ well water $+75 \%$ wastewater and $100 \%$ wastewater, respectively). 11,12 and 13 are irrigation intervals of 1,2 and 3 days, respectively. Means followed by the same letter within each seedling trait are not significantly different at $P<0.05$ as determined by Duncan's Multiple Range Test.

\subsection{Experiment at Complete Plant Stage}

Leaf Chlorophyll Content: By increasing wastewater concentration, leaf chlorophyll content was increased (Table 1, Fig. 2). Asano and Pettygrove (1987) and Jenkins et al. (1994) observed that plant irrigated by wastewater had darker green color than control. Drought reduced leaf chlorophyll content (Table 3). Irrigation interval of 4 days had chlorophyll content reduction of $51 \%$ compared to irrigation interval of 2 days. Drought reduced chlorophyll content in wheat (Saeidi et al. (2010) and maize (Nayyar 
and Gupta, 2006). It seems that drought destroys chloroplasts (Zarco et al., 2000) and disturbs activities of enzymes involving in photosynthetic pigment synthesis.

Table 1. Wastewater treatments on some oat traits

\begin{tabular}{|c|c|c|c|c|c|}
\hline Treatments $^{\mathrm{a}}$ & $\begin{array}{l}\text { Chlorophyll } \\
\text { (SPAD index) }\end{array}$ & $\begin{array}{c}\text { Relative } \\
\text { Water } \\
\text { Content (\%) }\end{array}$ & $\begin{array}{l}\text { Leaf Area }\left(\mathrm{cm}^{2}\right. \\
\left.\text { plant }^{-1}\right)\end{array}$ & $\begin{array}{l}\text { Leaf Weight } \\
\left.\text { (g plant }^{-1}\right)\end{array}$ & $\begin{array}{l}\text { Stem Weight } \\
\text { (g plant }^{-1} \text { ) }\end{array}$ \\
\hline S1 & $26.3 \mathrm{~d}$ & $72.1 \mathrm{a}$ & $53.4 \mathrm{c}$ & $2.87 \mathrm{~d}$ & $1.99 \mathrm{~d}$ \\
\hline $\mathrm{S} 2$ & $27.4 \mathrm{~cd}$ & $67.4 \mathrm{ab}$ & $55.4 \mathrm{c}$ & $3.00 \mathrm{~cd}$ & $2.13 \mathrm{c}$ \\
\hline S3 & $30.9 c$ & $62.8 \mathrm{bc}$ & $64.0 \mathrm{~b}$ & $3.11 b c$ & $2.16 \mathrm{c}$ \\
\hline S4 & $35.0 \mathrm{~b}$ & $57.7 \mathrm{c}$ & $67.4 \mathrm{ab}$ & $3.21 b$ & $2.31 \mathrm{~b}$ \\
\hline S5 & $43.0 \mathrm{a}$ & $48.4 \mathrm{~d}$ & $72.5 \mathrm{a}$ & $3.47 \mathrm{a}$ & $2.47 \mathrm{a}$ \\
\hline
\end{tabular}

a S1, S2, S3, S4 and S5 are different ratios of sewage-contaminated water (100\% well water, $75 \%$ well water $+25 \%$ wastewater, $50 \%$ well water $+50 \%$ wastewater, $25 \%$ well water $+75 \%$ wastewater and $100 \%$ wastewater, respectively).

${ }^{b}$ Means followed by the same letter within each column are not significantly different at $P<0.05$ as determined by Duncan's Multiple Range Test.
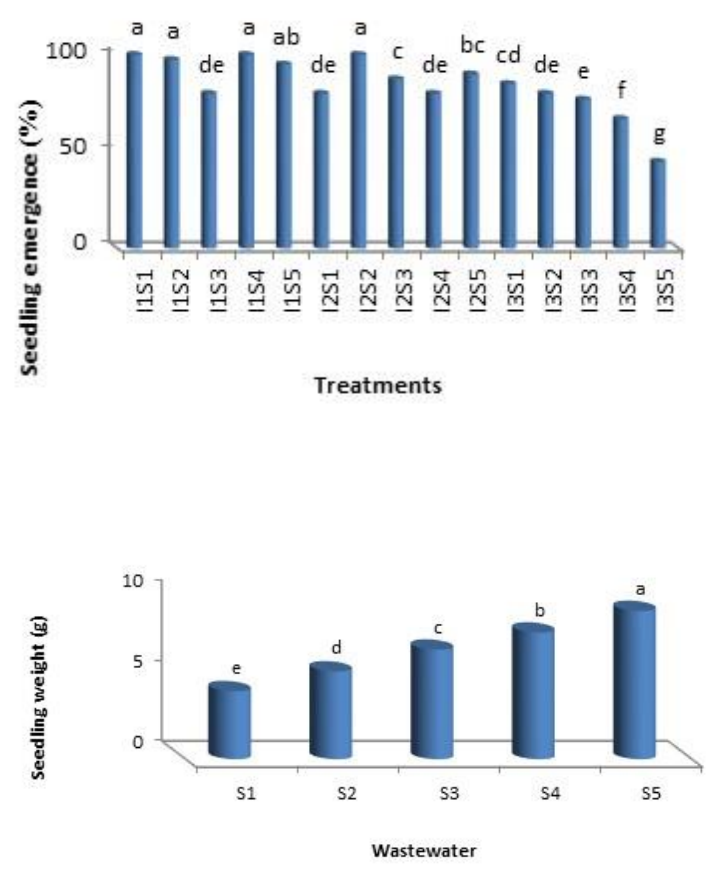

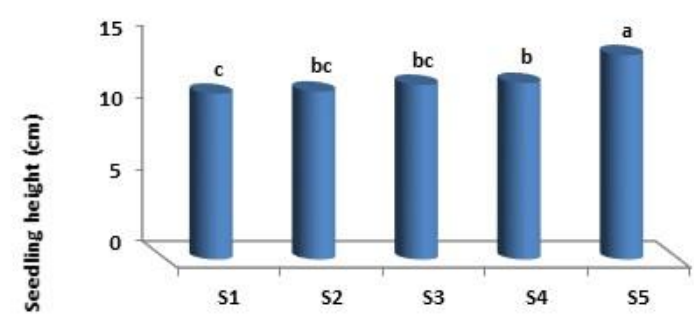

Wastewater

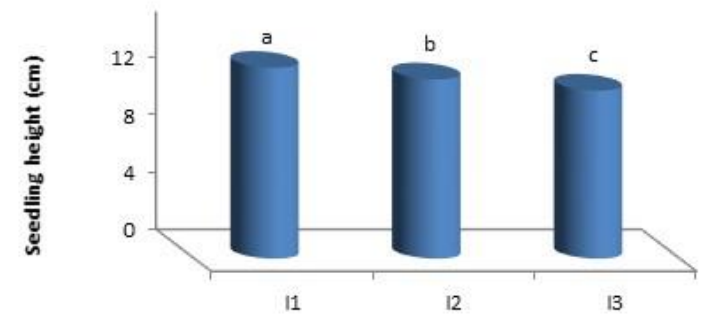

Irrigation interval

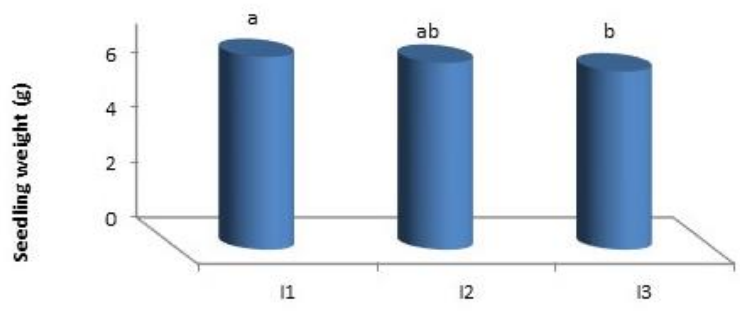

Irrigation interval

Figure 1. Effect of wastewater and irrigation interval on oat seedling traits

Leaf Relative Water Content: By increasing wastewater to well water ratio and drought, leaf relative water content was decreased (Table 1, Fig. 2). Irrigation interval of 4 days had a leaf relative water content 
reduction of $34 \%$ compared to irrigation interval of 2 days. Relative water content reduction is due to leaf water potential reduction and water suction reduction from soil. Sharif et al. (2007) reported similar results. Fu et al. (2004) reported that drought decreased relative water content and increased cell electrolyte leakage.

Leaf Area: By increasing wastewater to well water ratio, leaf area was increased, but drought reduced leaf area (Table 1, Fig. 2). Alizade et al. (2001) reported that wastewater increased leaf width in maize (Zea mays). Irrigation interval of 4 days had a leaf area reduction of $30 \%$ compared to irrigation interval of 2 days. Drought decreased leaf area and photosynthetic area in maize, so plant growth and biomass were reduced (Payero et al., 2006). Wastewater contains a great number of essential nutrients for increasing plant leaf area.

Leaf and Stem Weight: Plants irrigated by $100 \%$ wastewater and $100 \%$ well water produced the highest and lowest leaf and stem weight, respectively (Table 1, Fig. 2). Wastewater contains essential nutrients increasing cell volume and turgor so leaf weight increases (Jalali et al., 2010). Drought decreased leaf and stem weight (Table 3). Irrigation interval of 4 days had a leaf and stem weight reduction of $20 \%$ and $25 \%$ compared to irrigation interval of 2 days, respectively. Drought decreases growth rate in all dimensions. At first, drought reduces cell expansion by way of turgor reduction and cell division reduction. Drought also reduces photosynthesis through stomata closing and increases root to shoot ratio (Kafi et al., 2010).

Seed Number per Panicle: Different ratios of sewage-contaminated water had no significant effect on seed number per panicle. By increasing irrigation interval, seed number per panicle was decreased. Irrigation interval of 4 days had a seed number per panicle reduction of $7 \%$ compared to irrigation interval of 2 days (Table 4). Drought reduces seed number per spike through fertilization reduction (Sharif et al., 2007).

1000-seed Weight: Plants irrigated by $100 \%$ wastewater and $100 \%$ well water produced the highest and lowest 1000 -seed weight, respectively (Table 2, Fig. 2). Plants irrigated by $100 \%$ wastewater had a $1000-$ seed weight increase of $16.5 \%$ compared to plants irrigated by $100 \%$ well water. Increasing of 1000 -seed weight under $100 \%$ wastewater application can be attributed to plant appropriate nutrition and increasing photosynthetically active area during seed filling period (Ghanbari et al., 2007). By increasing irrigation interval, 1000-seed weight was decreased. Irrigation interval of 4 days had a 1000 -seed weight reduction of $25.3 \%$ compared to irrigation interval of 2 days (Table 1). Mohammad et al. (1996) reported that water deficit stress during flowering affected seed number per plant but after flowering reduced seed weight. Ali et al. (2007) found that deficit irrigation increased wheat 1000-seed weight compared to full irrigation. Drought at flowering stage reduces cell division of growing seed and reduces sink demand so 1000-seed weight is reduced (Saeidi et al., 2010).

Seed Yield: Plants irrigated by $100 \%$ wastewater and $100 \%$ well water produced the highest and lowest seed yield, respectively (Table 2, Fig. 2). Plants irrigated by $100 \%$ wastewater had a seed yield increase of $17 \%$ compared to plants irrigated by $100 \%$ well water. Seed yield increasing by wastewater was reported by many researchers in crop plants (Day et al., 1975; Day and Tucker, 1977; Ghanbari et al., 2007). Wastewater contains essential nutrients that promote plant growth. Wastewater improved oat seed yield components such as seed number per panicle and 1000-seed weight, so seed yield was increased. Plants irrigated by irrigation interval of 4 days had a seed yield reduction of $25 \%$ compared to plants irrigated by irrigation interval of 2 days (Table 4). It was reported that increasing irrigation interval decreased maize seed yield (Oktem et al., 2003) and oat forage yield (Mustafa Tahir et al., 2014). Deficit irrigation at wheat seed formation and maturity stages had the highest seed yield and saved water by $34 \%$ (Hassan et al., 2000). Drought reduces seed yield by reducing leaf area, crop growth rate, photosynthesis rate and seed yield components (Pannu and Singh, 1993) such as seed number per plant and 1000-seed weight (Samarah et al., 2004).

Biological Yield: Plants irrigated by $100 \%$ wastewater and $100 \%$ well water produced the highest and lowest biological yield, respectively (Table 2, Fig. 2). Alizade et al. (2001) reported that wastewater increased maize biological yield. Nitrogen, phosphorous and potassium are some common nutrients in wastewater that promote biomass production. Plants irrigated by irrigation interval of 4 days had a 
biological yield reduction of $24 \%$ compared to plants irrigated by irrigation interval of 2 days (Table 4 ). The results are in agreement with Payero et al. (2006) findings.
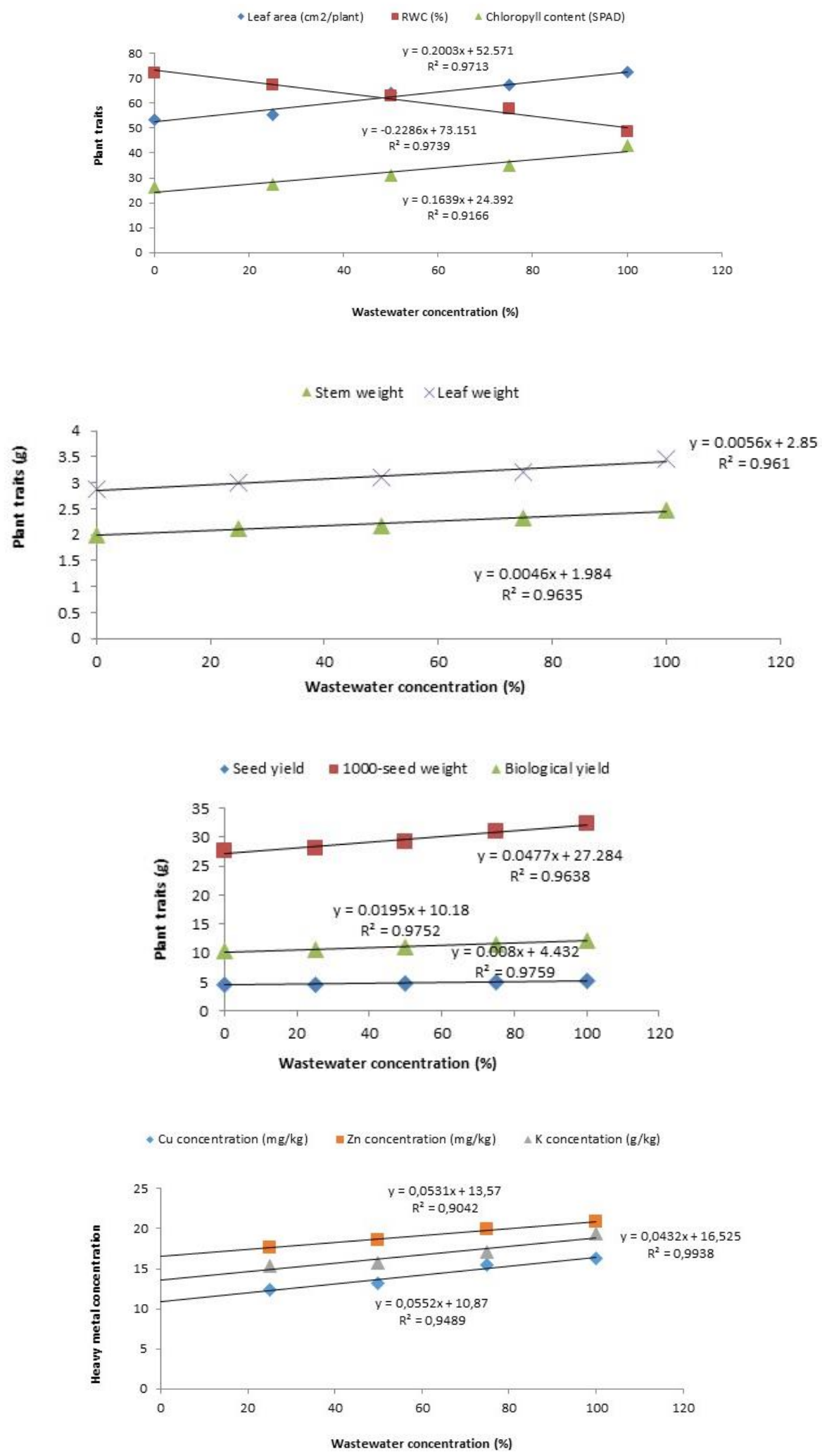

Figure 2. Regression between wastewater concentration and plant traits 
Copper Concentration: Plants irrigated by $100 \%$ wastewater and $100 \%$ well water produced the highest and lowest copper concentration, respectively (Table 2, Fig. 2). Copper concentration within oat seed was lower than permissive threshold that was $20 \mathrm{mg} \mathrm{kg}^{-1}$ for similar cereals (Beigi Harchegani and Banitalebi, 2013). High concentration of sodium within wastewater can be an antagonist to neutralize soil negative charges against micronutrients. So soil micronutrient concentrations and their absorption are increased (Jalali et al., 2010).

Zinc Concentration: Plants irrigated by $100 \%$ wastewater and $100 \%$ well water produced the highest and lowest zinc concentration, respectively (Table 2, Fig. 2). Plants irrigated by $100 \%$ wastewater had a zinc increase of $33 \%$ compared to plants irrigated by $100 \%$ well water. Feizi (2001) reported that wastewater increased copper and zinc concentration in tomato (Lycopersicum esculentum) fruit, stem and leaf. Zinc concentration within oat seed was lower than permissive threshold that was $50 \mathrm{mg} \mathrm{kg}^{-1}$ for similar cereals (Beigi Harchegani and Banitalebi, 2013). Some plants like Thlaspi caerulescens are hyperaccumulator of heavy metals like Zn (Pence et al., 2000). In phytoremediation, plants were used to remove contamination from the environment. For example water hyacinth (Eichchornia crassipes) is a useful plant for removal of zinc from wastewater. It seems that oat also has a potential to be used as phytoremediator. Rattan et al. (2005) reported that maize, irrigated by wastewater, produced seed that contained the lowest zinc concentration among other parts. Many people worry about irrigation by wastewater because of its heavy metals. According to our results, we did not observe any dangerous heavy metals accumulation by wastewater at least under our experiment condition. However other heavy metals such as cadmium and lead should be studied at the next researches to ensure. Microbial infection risk from wastewater to human is at least because oat is a forage crop and if its seed was used to feed animal, the risk sharply reduces. Because the seed is dry and its microbial infection is lower than fresh forage.

Sodium and Potassium Concentration: Different ratios of sewage-contaminated water and deficit irrigation had no significant effect on sodium concentration (data not shown). Plants irrigated by $100 \%$ wastewater and $100 \%$ well water produced the highest and lowest potassium concentration, respectively (Table 2, Fig. 2).

Table 2. Wastewater treatments on some oat traits

\begin{tabular}{ccccccc}
\hline Treatments & $\begin{array}{c}\text { 1000-seed } \\
\text { Weight } \mathbf{~ ( g ) ~}\end{array}$ & $\begin{array}{c}\text { Seed Yield } \\
(\mathbf{g} \text { plant }\end{array}$ & $\begin{array}{c}\text { Biological } \\
\text { Yield } \\
\left(\mathbf{g ~ p l a n t}^{-1}\right)\end{array}$ & $\begin{array}{c}\text { Copper } \\
\text { Concentration } \\
\left(\mathbf{m g ~ k g}^{-1}\right)\end{array}$ & $\begin{array}{c}\text { Zinc } \\
\text { Concentration } \\
\left(\mathbf{m g ~ k g}^{-1}\right)\end{array}$ & $\begin{array}{c}\text { Potassium } \\
\text { Concentration } \\
\left(\mathbf{g ~ k g}^{-1}\right)\end{array}$ \\
\hline S1 & $27.7 \mathrm{c}$ & $4.49 \mathrm{c}$ & $10.29 \mathrm{~d}$ & $12.40 \mathrm{c}$ & $17.67 \mathrm{e}$ & $15.37 \mathrm{~d}$ \\
\hline S2 & $28.1 \mathrm{c}$ & $4.59 \mathrm{c}$ & $10.65 \mathrm{~cd}$ & $13.16 \mathrm{c}$ & $18.54 \mathrm{~d}$ & $15.77 \mathrm{~d}$ \\
\hline S3 & $29.2 \mathrm{bc}$ & $4.77 \mathrm{bc}$ & $10.99 \mathrm{c}$ & $15.50 \mathrm{~b}$ & $19.87 \mathrm{c}$ & $17.04 \mathrm{c}$ \\
\hline S4 & $30.9 \mathrm{ab}$ & $5.04 \mathrm{ab}$ & $11.58 \mathrm{~b}$ & $16.22 \mathrm{~b}$ & $20.83 \mathrm{~b}$ & $19.37 \mathrm{~b}$ \\
\hline S5 & $32.2 \mathrm{a}$ & $5.26 \mathrm{a}$ & $12.26 \mathrm{a}$ & $18.13 \mathrm{a}$ & $23.65 \mathrm{a}$ & $22.82 \mathrm{a}$ \\
\hline
\end{tabular}

a S1, S2, S3, S4 and S5 are different ratios of sewage-contaminated water (100\% well water, $75 \%$ well water $+25 \%$ wastewater, $50 \%$ well water $+50 \%$ wastewater, $25 \%$ well water $+75 \%$ wastewater and $100 \%$ wastewater, respectively).

${ }^{b}$ Means followed by the same letter within each column are not significantly different at $P<0.05$ as determined by Duncan's Multiple Range Test.

Plants irrigated by $100 \%$ wastewater had a potassium increase of $48 \%$ compared to plants irrigated by $100 \%$ well water. Wastewater increased potassium concentration in maize compared to well water (Alizade et al., 2001; Tavassoli et al., 2010). Plants irrigated by irrigation interval of 4 days had a potassium reduction compared to plants irrigated by irrigation interval of 2 days (Table 4). Samarah et al., (2004) reported that drought reduced potassium, phosphor and nitrogen concentration in soybean. Some researchers believe that stress increases sodium and potassium absorption by plant. That is due to osmotic adjustment and potassium ion role in stomata opening. Sodium and potassium concentration within plant tissues under drought condition was lower than that of under well-watered condition. It is due to that under well-watered condition, monovalent ions (such as potassium and sodium) to divalent ions (such as calcium and magnesium) availability ratio were increased. But as soil is drying, clay colloids adsorb monovalent ions such as potassium and sodium strongly and their availabilities for plants were reduced (Kafi et al., 2010). 
Table 3. Irrigation interval effects on some oat traits

\begin{tabular}{|c|c|c|c|c|c|}
\hline $\begin{array}{l}\text { Irrigation } \\
\text { Interval }^{\mathrm{a}}\end{array}$ & $\begin{array}{c}\text { Chlorophyll } \\
\text { (SPAD index) }^{\text {b }}\end{array}$ & $\begin{array}{c}\text { Relative Water } \\
\text { Content (\%) }\end{array}$ & $\begin{array}{c}\text { Leaf Area } \\
\left(\mathrm{cm}^{2} \text { plant }^{-1}\right)\end{array}$ & $\begin{array}{l}\text { Leaf Weight } \\
\text { (g plant }^{-1} \text { ) }\end{array}$ & $\begin{array}{c}\text { Stem Weight } \\
\left(\text { g plant }^{-1}\right)\end{array}$ \\
\hline I1 & $43.5 \mathrm{a}$ & $72.9 \mathrm{a}$ & $73.5 \mathrm{a}$ & $3.43 \mathrm{a}$ & $2.49 \mathrm{a}$ \\
\hline 12 & $32.9 b$ & $63.9 b$ & $62.7 b$ & $3.21 b$ & $2.29 \mathrm{~b}$ \\
\hline 13 & $21.2 \mathrm{c}$ & $48.1 \mathrm{c}$ & $51.4 \mathrm{c}$ & $2.76 \mathrm{c}$ & $1.86 \mathrm{c}$ \\
\hline
\end{tabular}

\section{Conclusions}

Drought and $100 \%$ wastewater reduced seedling emergence. So at oat seedling emergence if drought occurs, irrigation with wastewater, especially at high concentration, should be avoided. Plants irrigated by $100 \%$ wastewater produced the highest seed yield and yield components. Concentrations of zinc, copper and potassium in the grain were increased by increasing concentrations of wastewater. Many people worry about irrigation by wastewater because of its heavy metals.

We did not observe any dangerous heavy metals accumulation by wastewater. However other heavy metals such as cadmium and lead should be studied at the next researches to ensure. Duration of experiment is another point of view. If wastewater is applied during several years, it will affect soil elements accumulation. Ultimately some elements may accumulate within plant tissues that should be studied at the next experiment.

Table 4. Irrigation interval effects on some oat traits

\begin{tabular}{cccccc}
\hline $\begin{array}{c}\text { Irrigation } \\
\text { Interval }\end{array}$ & $\begin{array}{c}\text { Seed Number } \\
\text { per Panicle }\end{array}$ & $\begin{array}{c}\text { 1000-seed } \\
\text { Weight (g) }\end{array}$ & $\begin{array}{c}\text { Seed Yield (g } \\
\left.\text { plant }^{-1}\right)\end{array}$ & $\begin{array}{c}\text { Biological } \\
\text { Yield (g plant } \\
\mathbf{1})\end{array}$ & $\begin{array}{c}\text { Potassium } \\
\text { Concentration } \\
\left.\mathbf{( g ~ k g}^{-1}\right)\end{array}$ \\
\hline 11 & $45.2 \mathrm{a}$ & $34.3 \mathrm{a}$ & $5.60 \mathrm{a}$ & $12.65 \mathrm{a}$ & $18.31 \mathrm{a}$ \\
\hline 12 & $43.3 \mathrm{~b}$ & $28.9 \mathrm{~b}$ & $4.70 \mathrm{~b}$ & $11.17 \mathrm{~b}$ & $18.20 \mathrm{a}$ \\
\hline 13 & $42.3 \mathrm{~b}$ & $25.6 \mathrm{c}$ & $4.18 \mathrm{c}$ & $9.64 \mathrm{c}$ & $17.71 \mathrm{~b}$ \\
\hline
\end{tabular}

a I1, 12 and 13 are irrigation intervals of 2, 3 and 4 days, respectively.

${ }^{b}$ Means followed by the same letter within each column are not significantly different at $P<0.05$ as determined by Duncan's Multiple Range Test.

\section{References}

Ali M.H., Hoque M.R., Hasan A.A. and Khair A. (2007), Effects of deficit irrigation on yield, water productivity and economic returns of wheat, Agr. Water Manage, 92, 151-161.

Alizade A., Bazari M.E., Velayati S., Hasheminia M. and Yaghmaie A. (2001), Irrigation of corn with wastewater, Pages 147-154. In: ICID Intertional Workshop on Wastewater Reuse and Management. Ragab R., Pearrce G., Chakgkim J., Nairizi S., Hamdy A. (Eds.), Seoul, Korea.

Asano T. and Pettygrove S. (1987), Using reclaimed municipal wastewater for irrigation, Calif. Agr., 41(3-4), 15-18.

Babran S. and Honarbakhsh N. (2008), Water status crisis in the world and Iran, Rahbord Journal, 48, 193-212.

Bahrani A. (2013), Effect of salinity on growth, ions distribution, accumulation and chlorophyll concentrations in two canola (Brassica napus L.) cultivars, American-Eurasian J. Agric. and Environ. Sci., 13, 683-689.

Barua D., Buragohain J. and Sarma S.K. (2011), Impact of Assam petroleum crude oil on the germination of four crude oil resistant species, Asian J. Plant Sci. and Res., 1, 68-76.

Beigi Harchegani H. and Banitalebi G. (2013), The effect of twenty-three years of surface irrigation with treated municipality wastewater on soil loading transfer to wheat and corn grains, and related health risks of some heavy metals, Journal of Water and Soil, 27(3), 570-580. 
Bhuiyan M.A.R., Rahman M.M., Shaid A., Bashar M.M. and Khan M.A. (2016), Scope of reusing and recycling the textile wastewater after treatment with gamma radiation, Journal of Cleaner Production, 112, 3063-3071.

Brady N. (1990), The nature and properties of soil. 10th edition, Macmillan publishing Co, New York.

Chaab A., Fathi G., Siadat A., Zand E. and Anafjeh Z. (2009), The interference effects of natural weed population on growth indices of corn (Zea mays L.) at different plant densities, Journal of Iranian Agronomy Research, 7, 391-400.

Chojnacka K., Chojnacki A., Gorecka H. and Gorecki H. (2005), Bioavailability of heavy metals from polluted soils to plants, Science of the Total Environment , 337, 175- 182.

Day A.D. and Tucker T.C. (1977), Effects of treated wastewater on growth, fiber, protein and amino acid content of sorghum grain, J. Environ. Qual., 6(3), 325-327.

Day A.D., Taher F.A. and Katterman F.R.H. (1975), Influence of treated municipal wastewater on growth fiber, acid soluble nucleotide, protein and amino acid content in wheat grain, J. Environ. Qual., 4(2), 167-169.

Feizi M. (2001), Effect of treated wastewater on accumulation of heavy metals in plant and soil, Pages 1180-1186, In: International Workshop on Wastewater Reuse and Management, Geof Pearce R., Changkim J., Nairizi S. and Hamdy A. (Eds), Seoul, Korea.

Fu J., Fry J. and Huang B. (2004), Minimum water requirements of four turf grasses in the transition zone, Hort Sci., 39, 1740-1744.

Ghanbari A., Abedi Koupai J. and Taie Semiromi J. (2007), Effect of municipal wastewater irrigation on yield and quality of wheat and some soil properties in Sistan zone, Journal of Water and Soil Science, 10(4), 59-75.

Gunes A., Inal A., dak M.S., Bagci E. G., Cicek N. and Eraslan F. (2008), Effect of drought stress implemented at preor post-anthesis stage on some physiological parameters as screening criteria in chickpea cultivars, Russian $\mathrm{J}$ Plant Physl., 55(1), 59-67.

Hassan A.A., Sarkar A.A., Karim N.N. and Ali M.H. (2000), Irrigation schedule and deficit irrigation for wheat cultivation, Bangladesh Journal of Agriculture, 25, 43-50.

Jadia C.D. and Fulekar M.H. (2008), Phytoremediation: The application of vermicompost to remove zinc, cadmium, copper, nickel and lead by sunflower plant, Environ. Eng. Manag. J., 7, 547-558.

Jalali A., Galavi M., Ghanbari A., Ramroudi M. and Yousef Elahi M. (2010), Effects of irrigation with municipal treated wastewater on yield and heavy metal uptake in forage sorghum (Sorghum bicolor L.), Water and Soil Science, 52, 15-24.

Jenkins C.R., Papadoputos I. and Stylianou Y. (1994), Pathogens and wastewater use for irrigation in Cyprus, Pages 978-989, In: Proceedings of International Conference on Land and Water, Valenzano, Bari, Italy.

Jomova K. and Morovic M. (2009), Effect of heavy metal treatment on molecular changes in root tips of Lupinus luteus L., Czech Journal of Food Science, 27, S386-S389.

Kafi M., Borzooiyy A., Salehi M., Kamandi A., Masoumi A. and Nabati J. (2010), Environmental stress physiology in plants, 502 p., Mashhad Jihade-Daneshgahi Press, Iran.

Kaya M.D., Okcu G., Atak M., Cikili Y. and Kolsarici O. (2006), Seed treatment to overcome salt and drought stress during germination in sunflower (Helianthus annus L.), Europ. J. Agron., 24, 291-295.

Kopittke P.M. (2006), Effect of Cu toxicity on growth of Cowpea (Vigna unguiculata). Plant and soil, 279, $287-296$.

Li W., Khan M.A., Yamaguchi S. and Kamiya Y. (2005), Effects of heavy metals on seed germination and early seedling growth of Arabidopsis thaliana, Plant Growth Regul., 46, 45-50.

Mara D. and Cairncross S. (1989), Guidelines for safe use of wastewater and excreta in agriculture and aquaculture: measures for public health protection, World Health Organization, Gevena.

Marschner H. (1995), Mineral nutrition of higher plants, 2nd Edition, Academic Press, London, UK.

Meftahi M. (2011), Study of effect of Ilam filtered wastewater on heavy metals accumulation and nutritional value in sorghum, M. Sc. Thesis, Water Engineering Department, Agriculture College, Razi University, Kermanshah, Iran.

Mohammad J., Naziri M., Nazir A., Shah D. and Jamal H. (1996), Wheat yield component as affected by low water stress at different growth stage, Sarhad Journal of Agriculture, 12, 19-26. 
Moosavi S.A., Noori Emamzadei S.M.R. and SamadiBroojeni H. (2013), Application crises of unusual waters in agriculture. In: 1th national congress on water resources crises and agriculture, Iran irrigation and drainage society, 12 Feb, Khorasgan Islamic Azad University, Isfahan, Iran.

Mustafa Tahir, G.H., Haq A., Khaliq T., Rehman M. and Hussain S. (2014), Effect of different irrigation levels on yield and forage quality of oat (Avena sativa), App. Sci. Report, 3(1), 42-46.

Nayyar H. and Gupta D. (2006), Differential sensitivity of C3 and C4 plant to water deficit stress: Association with oxidative stress and antioxidants, Envir. Exp. Bot., 58,106-113.

Oktem A., Simsek M. and Oktem G. (2003), Deficit irrigation effects on sweet corn (Zea Mays saccharata strut) with drip irrigation system in an arid region I. Water yield relationship, Agr. water manage, 61(1), 63-74.

Pais I.J. and Benton Jones J. R. (1997), The handbook of trace elements. St. Lucie press Boca Raton pub., Florida.

Pannu R.K. and Singh D.P. (1993), Effect of irrigation on water use efficiency, growth and yield. I: mung bean, Field Crop Res., 31, 87-100.

Payero J.O., Steven R.A., Suat B.C. and Tarkalson A. (2006), Yield response of corn to deficit irrigation in the semiarid climate, Agr. Water Manage., 84, 101-112.

Pence N.S., Larsen P.B., Ebbs S.D., Letham D.L.D., Lasat M.M., Garvin D.F., Eide D. and Kochian L.V. (2000), The molecular physiology of heavy metal transport in the $\mathrm{Zn} / \mathrm{Cd}$ hyperaccumulator Thlaspi caerulescens, Proceedings of the National Academy of Sciences, 97, 4956-4960.

Prazeres A.R., Rivas J., Almeida M.A., Patanita M., Dôres J. and Carvalho F. (2016), Agricultural reuse of cheese whey wastewater treated by $\mathrm{NaOH}$ precipitation for tomato production under several saline conditions and sludge management, Agricultural Water Management ,167, 62-74.

Rahimi A., Jahansoz M. R., Rahimian Mashhadi H., Postini K. and Sharifzadeh F. (2006), Effect of iso-osmotic salt and water stress on germination and seedling growth of two Plantago species, Pakistan J Biol Sci., 9, 2812-2817.

Rattan R.K., Datta S.P., Chhonkar P.K., Suribabu K. and Singh A.K. (2005), Long-term impact of irrigation with sewage effluents on heavy metal content in soil, crop and groundwater a case study, Agr Ecosyst and Environ., 109, 310-322.

Saeidi M., Moradi F., Ahmadi A., Spehri R., Najafian G. and Shabani A. (2010), The effects of terminal water stress on physiological characteristics and sink- source relations in two bread wheat (Triticum aestivum L.) cultivars, Iranian Journal of Crop Sciences, 12(4), 392-408.

Salardiny A. (2005), Soil Fertility, University of Tehran Press, Iran, 434 p.

Samarah N., Mullen R. and Cianzio S. (2004), Size distribution and mineral nutrients of soybean seed in response to drought stress, Journal of Plant Nutrition, 27(5), 815-835.

Schaller H. (2003), The role of sterol- sin plant growth and development, Progress in Lipid Res. Planta., 42, 63-175.

Sharif S., Saffari M. and Emam Y. (2007), The Effect of drought stress and cycocel on barley yield (Cv. Valfajr), Journal of Water and Soil Science, 10 (4), 281-291.

Tavassoli A., Ghanbari A., Amiri E. and Paygozar Y. (2010), Effect of municipal with manure and fertilizer on yield and quality characteristics of forage in corn, Africa. J. Biol, 9(17), 2515-2520.

Yara. 2015. World Oat Production. Accessed at 29/7/2015. http://yara.co.uk/crop-nutrition/crops/oats/keyfacts/world-oat-production/

Yoon C.G. and Kwun S.K. (2001), Feasibility study of reclaimed wastewater irrigation to paddy rice culture in Korea, Pages 127-136, In: ICID International Workshop on Wastewater Reuse and Management. Ragab R., Pearce G., Changkim J., Nairizi S., Hamdy A. (Eds), Seoul, South Korea.

ZarcoTejada P.J., Miller J.R., Mohammad G.H., Noland T.L. and Sampson P.H. (2000), Chlorophyll fluorescence effects on vegetation apparent reflectance, Remote Sens. Environ., 74, 596-608. 